\title{
Analisis Bioinformatika Gen Cat (Homo sapiens): Penyandi Enzim Antioksidan Katalase dan Mutasi C330T pada Diabetes Melitus Tipe 1
}

\author{
Bioinformatics Analysis of Cat Gene (Homo sapiens): Catalase Antioxidant \\ Enzyme Coding and C330T Mutations in Type 1 Diabetes Mellitus
}

\author{
Linda Weni \\ Department of Bbiochemistry, Fakulty of School, YARSI University, Jakarta \\ Menara YARSI, Kav 13. Jl Let.Jend.Soeprapto, Cempaka Putih, Jakarta Pusat 10510 \\ E-mail: linda.weni@yarsi.ac.id
}

KATA KUNCI katalase; mutasi SNP C (330) T; penelitian in silico; defisiensi katalase; diabetes

\begin{abstract}
ABSTRAK
Katalase (EC 1.11.16) adalah merupakan enzim antioksidan yang bertindak sebagai biokatalisator dengan mengubah $\mathrm{H} 2 \mathrm{O} 2$ menjadi $\mathrm{H} 2 \mathrm{O}$ dan O2. Enzim ini berperan penting dalam meregulasi metabolisme $\mathrm{H} 2 \mathrm{O} 2$. Hidrogen peroksida adalah merupakan sebuah molekul kecil hasil samping dari metabolisme. Kelebihan $\mathrm{H} 2 \mathrm{O} 2$ akibat defisiensi Katalase, menyebabkan kerusakan yang signifikan pada protein, DNA, RNA dan lipid sehingga hal ini juga berperan pada patogenesis berbagai penyakit, termasuk diabetes. Dalam studi in silico ini, perubahan yang terjadi pada mutasi SNP (single nucleotide polymorphism) C (330) T (rs 10011179) dari gen CAT akan diselidiki, termasuk hubungannya dengan risiko peningkatan resiko diabetes. Untuk itu dilakukan pencarian bioinformasi, diantaranya informasi tentang gen, protein dan penelusuran informasi penting lainnya yang dapat digunakan sebagai informasi pendukung penelitian. Analisis bioinformatika gen CAT dilakukan dengan menggunakan beberapa program open source dari situs web. Pada penelitian ini ternyata terjadi mutasi misssense SNP Ala110Val (C330T, rs1001179) yang ditemukan pada struktur 3D CAT pada urutan asam amino ke-110 (C330T) yang mengganggu fungsi amidasi protein CAT. Mutasi ini menyebabkan berkurangnya ekspresi gen CAT, yang berakibat pada berkurangnya aktivitas CAT sebagai biokatalis dan sebagai enzim antioksidan. Hal ini terkait dengan peningkatan risiko diabetes tipe 1 .
\end{abstract}

KEYWORDS catalase; SNP C (330) T mutation; in silico study; catalase deficiency; diabetes

ABSTRACT Catalase (EC 1.11.1.6) is an antioxidant enzyme that acts as a biocatalyst in converting $\mathrm{H}_{2} \mathrm{O}_{2}$ to $\mathrm{H}_{2} \mathrm{O}$ and $\mathrm{O}_{2}$. This enzyme has an important role in regulating $\mathrm{H}_{2} \mathrm{O}_{2}$ metabolism. Hydrogen peroxide is a 
reactive small molecule that is produced as a result of metabolism. Excess $\mathrm{H}_{2} \mathrm{O}_{2}$ due to deficiency of catalase will cause significant damage to protein, DNA, RNA and lipids so that it plays a role in the pathogenesis of various diseases including diabetes. In this in silico study, changes that occur in the SNP (single nucleotide polymorphism) C (330) T (rs 10011179) mutation of the CAT gene will be investigated and their association with the risk of developing diabetes. For this reason, bioinformation searches are carried out, including knowledge of genes, proteins and other important information tracing that can be used as research supporting information. The bioinformatics analysis of the CAT gene was carried out using several open source programs from the website. In this study, it turns out that the SNP Alal10Val misssense mutation (C330T, rs1001179) is found in the 3D CAT structure at the $110^{\text {th }}$ amino acid sequence (C330T) which interferes the amidation function of the CAT protein. This mutation causes reduced CAT gene expression, which results in reduced CAT activity as a biocatalyst and as an antioxidant enzyme. This is associated with an increased risk of developing type 1 diabetes.

\section{PENDAHULUAN}

Katalase adalah merupakan salah satu enzim antioksidan yang berperan sebagai biokatalisator dalam perubahan $\mathrm{H}_{2} \mathrm{O}_{2}$ menjadi $\mathrm{H}_{2} \mathrm{O}$ dan $\mathrm{O}_{2}$. Enzim ini mempunyai peran penting dalam meregulasi metabolisme $\mathrm{H}_{2} \mathrm{O}_{2}$. Hidrogen peroksida adalah merupakan sebuah molekul kecil reaktif yang dihasilkan sebagai hasil metabolisme. Kelebihan $\mathrm{H}_{2} \mathrm{O}_{2}$ akan menyebabkan kerusakan yang signifikan pada protein, DNA, RNA dan lipid.

Dalam jumlah sedikit, $\mathrm{H}_{2} \mathrm{O}_{2}$ dapat menstimulan terjadinya aktivasi insulin signaling pada proses pembentukan insulin. Namun sebaliknya, peningkatan jumlah hidrogen peroksida sebagai akibat dari defisiensi katalase berperan penting terhadap patogensis berbagai penyakit, diantaranya adalah diabetes melitus.

Dari berbagai penelitian diketahui akatalasemia adalah salah satu hasil dari mutasi homozigot pada gen katalase yang terdistribusi pada 12 mutasi. Telah diketahui adanya hubungan antara akatalasemia dengan peningkatan resiko terjadinya diabetes melitus khususnya pada wanita.

Hubungan antara polimorfisme gen katalase dengan berbagai penyakit telah dilaporkan dalam berbagai penelitian. Courtney B Casp pada tahun 2002 melaporkan bahwa adanya hubungan antara mutasi gen pada katalase dengan resiko terjadinya vitilago (Courtney, 2002). Dari analisa terhadap kelompok kasus dan kontrol didapat bahwa T/C Single Nucleotide Polymorphism (SNP) pada exon 9 dari gen CAT yang dideteksi dengan enzim restriksi endonuklease $\mathrm{BstX} \mathrm{I}$, didapat hubungan antara gen CAT dan suspektibilitas vitiligo. Selain itu polimorfisme pada gen katalase juga berhubungan dengan penyakit Alzheimer. Chisdiakov DA (2004) melakukan penelitian kaitan antara diabetes tipe 1 dan tiga SNPs pada gen CAT. Dari penelitian ini didapatkan bahwa mutasi pada T1667T, C262T dan C330T dari gen CAT dengan locus pada chromoson $11 \mathrm{p} 13$ 
berhubungan kuat dengan diabetes tipe 1 yang terjadi pada kelompok pasien Rusia (Chisdiakov, 2004).

Pada makalah ini pembahasan difokuskan pada penelusuran gen CAT yang dikaitkan dengan resiko kejadian diabetes akibat mutasi pada C(330)T (rs 10011179).

Pada tulisan ini akan dibahas peran mutasi SNP (single nucleotide polymorphisme) pada C(330)T (rs 10011179) gen CAT pada diabetes tipe 1. Untuk itu dibutuhkan, baik pengetahuan tentang gen, protein maupun penelusuran informasi penting lainnya yang dapat digunakan sebagai informasi pendukung dalam suatu penelitian. Dengan informasi ini diharapkan penelitian dapat dilakukan dengan lebih terarah dan mudah.

\section{METODOLOGI Material}

Gen CAT diperoleh dari situs www.ncbl.gov dengan accesion number NC_000011.10 (34438925..34472060), mRNA CAT dengan accession number NM_ 001752 dan protein dengan accession number NP_001743.1

\section{Metode}

Analisis bioinformatika gen CAT dilakukan dengan menggunakan beberapa program open source dari website berikut ini:

1. Analisa struktur, transkrip dan fungsi protein precusor CAT dilakukan dengan menggunakan database bioinformatika dari situs www.ncbi.nlm.gov menu gen dan PubMed, www, uniprot.org dan www.enseble.org

2. Analisis mutasi pada C330T dilakukan menggunakan situs www.uniprot.com, situs www.ncbl.nml.gov menu OMIM dan SNP, serta mengacu pada literatur (Chistiakov,2004,2006).
3. Analisis komposisi, profil, dan topologi protein prekusor CAT wild type dan mutan menggunakan situs atau program www.expasy.org TMHMM, NetNGlyc dan http://bioinf.cs.ucl.ac.uk/psipred/ dalam menu PSIPRED dan http://www.ebi.ac.uk

4. Analisis struktur sekunder melalui situs http://bioinf.cs.ucl.ac.uk/ menu PSIPRED $\mathrm{v}$ 3.3. dan 3D protein prekusor CAT serta analisis komparatif dengan tipe mutan menggunakan situs www.pdb.org menu Swiss Model dan software PYMOL

5. Primer didisain untuk mengamplifikasi gen CAT wild type dalam proses PCR yang kemudian dianalisa polimorfismenya dengan metoda RFLP dan sekuensing. Disain primer dilakukan dengan menggunakan situs http://www.ncbi.nlm.gov menu BLAST. Analisis situs restriksi pada gen dilakukan menggunakan software REBASE dengan pilihan NEBcutter.

ISI

Analisis CAT: Struktur Gen, Transkrip mRNA dan Protein

Informasi mengenai gen CAT ditelusuri melalui situs http:// www.ncbi.nlm.gov menu gen menggunakan reference sequence (RefSeq, Mai 2016) dengan accesion number NC_000011.10 tersusun mulai daerah komplemen (34438925.34472060). Gen ini berlokasi di kromosom 13 dan mempunyai 13 ekson dengan panjang basa nukleutida $34 \mathrm{Kbp}$.

Gen ini merupakan tipe gen pengkode protein yang menghasilkan enzim antioksidan katalase Katalase (EC 1.11.1.6) merupakan biokatalisator dalam mendekomposisi hidrogen peroksida membentuk oksigen dan air. Katalase adalah merupakan enzim intraseluler yang 
utama, yang terkonsentrasi pada eritrosit, dan liver pada mamalia. Enzim ini kadangkala ditemukan juga pada ginjal. Pada jaringan, enzim ini ditemukan di peroksisom (Quan et al., 1986).

Katalase adalah merupakan protein tetramer dengan ukuran $244 \mathrm{kD}$ dengan 222 molekul yang simetris yang membentuk tiap sub unit yang identik dengan ukuran masing-masing 59,7 kD. Tiap unit terdiri dari 527 residu asam amino, satu grup heme yaitu Fe(III) prtoporphyrin IX, dan sebuah molekul NADPH (Ogata,1991; Ogata et al., 2008; Kirkman, 1984; Ko et al., 2000).

Dari hasil isolasi dan identifikasi gen katalase pada manusia didapatkan bahwa gen ini mempunyai panjang $34 \mathrm{~kb}$ dan terdiri 13 exon dan 12 intron dan terdapat pada chromosom 11, pita p13. Disamping itu didapat bahwa daerah upstream dari gen tidak berisi TATA box. Daerah ini berisi GC (67\%) dan berisi beberapa sekuen CCAAT dan GGGCGG yang membentuk bagian promotor. Translasi dari mRNA katalase dimulai pada upstream asam amino terminal Ala dari residu katalase (Quan, Kumeluk, 1986). Polimorphisme terdapat pada promotor, 5' dan 3' pada untranslated region (UTR) exon dan intron (Sato et al., 1992; Toda et al., 1997). Gen CAT terletak pada daerah 34.460.47134.493.606 base pair pada chromosom 11.

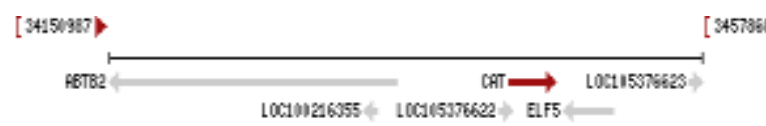

Chromosome11NC_000011.10

Gambar 1. Lokasi gen CAT (Homo sapiens) pada kromosom 11

Gen ini mempunyai 5 transkripsi yaitu CAT 001 dengan panjang basa nukleotida 2302 bp yang merupakan protein coding dari katalase yang terdiri atas 527 asam amino. Empat transkripsi lain bukan merupakan protein coding melainkan berperan dalam proses transkripsi yaitu CAT 002 dengan panjang nuklotida 752 bp, CAT 003 dengan panjang nukleotida 562 bp, CAT 004 dengan panjang nukleotida $354 \mathrm{bp}$, dan CAT 005 dengan panjang nukleotida 1020 bp.

Hasil pencarian mRNA CAT melalui situs www.ncbi.gov menu gen dengan accession number NM_ 001752 mempunyai panjang sekuen 2300 bp, berbentuk linear. Hasil transkripsi menunjukkan CAT mempunyai 13 ekson (ekson 1 posisi basa pada basa 1...155, ekson 2 posisi basa pada basa 157 ...327, ekson 3 posisi basa pada basa 328..438, ekson 4 posisi basa pada basa 359..569, ekson 5 posisi pbasa pada basa $570 . .674$, ekson 6 posisi basa pada basa $675 \ldots 800$, ekson 7 posisi basa pada basa $801 . . .992$, ekson 8 posisi basa pada 993 ...1145, ekson 9 posisis basa pada 1146...1284, ekson 10 posisi basa pada 1285..1415, ekson 11 posisi basa pada basa $1416 \ldots 1523$, ekson 12 posisi basa pada basa 1524 ...1607, ekson 13 posisi basa pada basa 1608 ...2300.

Protein CAT diambil melalui situs www.ncbi.nml.gov menu protein dengan accesion number NP_001743 terdiri dari 527 asam amino dengan bentuk linear. Melalui situs www.ncbi.nml.gov menu BLAST-protein BLAST, dapat ditelusuri kemiripan (homologi) sekuen protein CAT Homo sapiens dengan spesies lain (orthologi) atau dengan sekuen protein lain (paralogi) dalam Homo sapiens itu (dalam spesies yang sama). Berdasar nilai identifikasi (query coverage) 100\%, nilai $\mathrm{E} \leq 0$, sumber sekuen referensi (refseq) yang serupa (NP), maka diambil Pongo abelii sebagai orthologi. Untuk orthlogi ini, diambil accesion number (sequence ID) NP_001124739.136652.1 (CAT, Pongo abelii) dimana didapat tingkat kemiripan $98 \%$ dan untuk paralogi adalah 
dengan accession number (sequence ID) AAK29181.1 (CAT, Homo sapiens) dengan tingkat kemiripan $99 \%$.

Dari data www.uniprot.org diketahui bahwa CAT (Pongo abelii) dengan acession number Q5RF10 (CATA_PONAB) terdapat pada organisme yang bersifat aerobik dan berfungsi dalam melindungi sel dari efek toksik $\mathrm{H}_{2} \mathrm{O}_{2}$ serta menstimulasi pertumbuhan sel.

Berdasarkan data yang diperoleh dari http;//www.uniprot.org menu uniprot $\mathrm{KB}$ juga diketahui bahwa protein CAT berlokasi di peroksisom dan memiliki fungsi molekuler sebagai enzyme binding, protein homodimerization activity dan receptor binding. CAT berfungsi sebagai enzim antioksidan yang membantu sebagai katalis proses perubahan $\mathrm{H}_{2} \mathrm{O}_{2}$ menjadi $\mathrm{H}_{2} \mathrm{O}$ dan $\mathrm{O}_{2}$. Disamping itu juga berfungsi sebagai kofaktor heme dan $\mathrm{NADP}^{+}$. CAT mempunyai gugus aktif pada posisi 75-75 dan 148-148 serta sebagai metal binding dari Fe pada ligand Heme.

\section{Ekspresi Dan Fungsi Klinis CAT Pada Diabetes}

CAT merupakan gen yang menyandi protein katalase. Katalase berfungsi sebagai biokatalisator dalam dekomposisi hidrogen peroksida menjadi oksigen dan air. Hal ini membantu melindungi sel dari sifat toksik hidrogen peroksida. Aktivitas katalitik dari katalase adalah sebagai berikut :

$$
2 \mathrm{H}_{2} \mathrm{O}_{2} \longleftrightarrow \mathrm{O}_{2}+2 \mathrm{H}_{2} \mathrm{O}
$$

Dari sekuensing gen CAT untuk semua exon , exon/intron junctions, dan daerah 5-prime dan 3-prime seperti pada akatalasemia tipe Jepang. Wen, et al, pada tahun 1990 menemukan bahwa kelainan genetik dihasilkan akibat splicing mutation, yaitu subsitusi $\mathrm{G}$ terjadi pada posisi ke 5 dari intron 4. Pada studi menggunakan chimeric gene yang terdiri atas gen normal dan gen mutan dan sebagian gen alpha globin, Wen menemukan bahwa gen mutan terjadi bila gen tsb tersusun sebagai COS-7, dimana splicing abnormal terjadi (Wen et al., 1990).

Mutasi yang sama terjadi pada DNA pada kelompok akatalasemia yang lain (Wen, et al., 1990). Kishimoto, et al pada 1992 menemukan mutasi yang sama pada 2 pasien Jepang yang tidak ada keterkaitan genetik, dan menyimpukan bahwa hanya ada mutasi single pada allelle yang tersebar pada populasi Jepang. Penelitian lain dari Hirono et al (1995) menemukan polimorfisme akatalasemia pada populasi Jepang terjadi pada CAT, 1-BP, 358T. Pada individu Jepang dengan akatalesemia, Hirono mengindentifikasi suatu homozigous 1-bp deletion (358T) pada exon 4 dari gen CAT, yang menyebabkan terjadinya frameshift dan premature termination codon.

Dari studi literatur diketahui mutasi CAT pada C330T terjadi pada daerah promotor, dan merupakan mutasi missense dimana terjadi subsitusi asam amino Alanin menjadi Valin (Ala110Val, rs 1001179 ). Mutasi ini terjadi akibat perubahan translasi protein nomor 110 yang mengubah kodon GCC menjadi GTC. Mutasi ini secara klinis mempunyai keterkaitan dengan resiko terjadinya diabetes tipe 1 (Forsberg et al., ).

Dari berbagai penelitian diketahui bahwa, mekanisme kerja katalase pada diabetes tipe 1 adalah dengan cara meredam stres oksidatif yang ditimbulkan akibat kelebihan $\mathrm{H}_{2} \mathrm{O}_{2}$ yang dapat merusak sel $\beta$ pankreas sebagai penghasil insulin.

Mekanismenya adalah dengan cara katalase berfungsi sebagai enzim 
antioksidan yang berfungsi sebagai biokatalisator dengan merubah $\mathrm{H}_{2} \mathrm{O}_{2}$ sebagai radikal bebas yang reaktif menjadi molekul $\mathrm{H}_{2} \mathrm{O}$ dan $\mathrm{O}_{2}$ yang tidak reaktif Dengan cara ini efek toksik dari $\mathrm{H}_{2} \mathrm{O}_{2}$ yang merusak sel $\beta$ pankreas dapat diminimalisir. Seperti yang telah dilaporkan dari berbagai penelitian defisiensi katalase akan berakibat pada kurangnya aktivitas enzim anti oksidan katalase, sehingga dapat menimbulkan akatalasemia yang merupakan faktor resiko terjadinya diabetes tipe 1 . Hal ini disebabkan karena terjadinya mutasi gen yang berasosiasi pada terjadinya akatalasemia (Kodydkova, 2011; Chistiskov, 2004, 2006; Tamai, 2007; Ogata, 1991; Goth, 2000).

\section{Analisis Protein CAT: Komposisi, Profil, dan Lokasi}

Untuk mengetahui komposisi protein CAT digunakan situs www.expasy.org menu ProtPram. Dari hasil penelusuran ProtPram diketahui ada perbedaan antara mutan C330T CAT dengan protein normalnya, diantaranya adalah : berat molekul mutan C330T CAT adalah 59784,73\% Ala menjadi 7,8\% dan Val menjadi 7,2\%; Formula menjadi $\mathrm{C}_{2683} \mathrm{H}_{4067} \mathrm{~N}_{753} \mathrm{O}_{779} \mathrm{~S}_{14} ;$ stabilitas index menjadi 29,99 dan stabilitas alifatik adalah 68,65, serta GRAVY menjadi0,58 .

Untuk melihat adanya perbedaan topologi protein (hidrofobisitas) protein CAT yang normal dan mutan dilakukan analisis menggunakan program pada web www.expasy.org. Sifat hidrofobik dianalisa menggunakan Hphob./Kyte \& Doolittle. Hasil analisa menunjukkan kedua protein pada posisi 330 mempunyai nilai skala Hphob./Kyte \& Doolittle $<0,5$, sehingga disimpulkan kedua protein bukanlah protein hidrofobik.
Prediksi apakah protein CAT normal dan mutan merupakan protein transmembran dianalisis menggunakan skala asam amino Transmembrane tendency. Hasil analisa menunjukkan angka $<0,5$, sehingga dapat disimpulkan bahwa protein ini bukan protein transmembran.

Selanjutnya dilakukan analisa terhadap sifat polaritas protein CAT normal dan mutan menggunakan web www.expasy.org situs Protscale menggunakan menu skala Polaritas Zierman. Dari hasil analisa ini didapatkan untuk kedua protein pada posisi mutasi C330T didapatkan nilai yang hampir sama yaitu skor 28. Ini menunjukkan bahwa protein CAT normal dan mutan mempunyai polaritas yang cukup tinggi. Hal ini didukung oleh data sifat hidrofobiknya yang < 0,5 yang menunjukkan sifat yang lebih hidrofilik.

Analisa terhadap prediksi heliks untuk protein CAT normal dan mutan dilakukan untuk memastikan bahwa protein ini bukanlah protein transmembran. Untuk itu dilakukan analisa terhadap kemungkinan adanya struktur heliks pada transmembran proteinnya. Analisis dilakukan menggunakan program predicting transmembran protein topology with a hidden Markov model (TMHMM).

Dari data di atas untuk kedua protein tidak terdapat nilai $\mathrm{Tm}$ yang menunjukkan bahwa protein ini adalah bukan protein transmembran. Oleh karena itu dapat disimpulkan bahwa protein CAT normal dan mutan adalah bukan protein transmembran. Namun dari data MEMSAT3 dan MEMSAT-SVM didapatkan data bahwa CAT protein transmembran. Dari data tersebut didapatkan bahwa tidak ada sinyal peptida yang terdeteksi, terdapat 1 buah pore lining helix pada posisi 445-468, dan 
1 transmembran helix dimana $\mathrm{N}$ terminalnya berada diluar ekstraseluler. Analisa selanjutnya dilakukan untuk melihat apakah protein CAT normal dan mutan mengalami modifikasi pasca translasi. Untuk itu digunakan analisis protein program SignalP dari web http://www.cbs.dtu.dk/service menu Signal P.

Dari hasil analisa didapatkan bahwa kedua protein bukan protein transmembran, dimana tidak ditemukan adanya sinyal peptid $a$ pada kedua protein CAT normal maupun mutan. Sinyal peptida adalah sinyal N-terminal yang mengarahkan protein melintasi membran ER pada eukariot. Namun dari data yang didapat dari web www.expasy.org menu TargetP, tidak terdapat perbedaan yang signifikan dari kedua protein dimana mTP CAT normal adalah 0,094 dan mutan 0,095 , SP yang menunjukkan sinyal Peptida untuk CAT normal 0,61 dan mutan 0,60. Dari data ini dapat disimpulkan, karena kedua protein ini mempunyai sinyal peptida, maka protein CAT normal dan mutan termasuk kelompok protein secretory.

Glikosilasi merupakan proses penting modifikasi pasca translasi yang berpengaruh pada proses pelipatan, lokalisasi, kelarutan, antigenisitas, aktivitas biologis, serta interaksi protein dengan sel. Untuk menganalisa glikolasi digunakan software NetGlyc. Hasil analisa menunjukkan bahwa protein CAT normal memiliki 4 motif glikosilasi. Mutasi rs1001179 ternyata tidak mengubah situs glikosilasi pada protein CAT mutan. Hal ini tidak merubah fungsi penting dari protein CAT.

\section{Analisis Protein CAT: Struktur sekunder dan 3D}

Analisa terhadap struktur protein berperan penting dalam memahami fungsi protein, rekontruksi terhadap sruktur protein, dan studi terhadap interaksi yang terjadi antara protein. Analisa terhadap struktur sekunder protein dilakukan dengan menggunakan situs http://bioinf.cs.ucl.ac.uk/ menu PSIPRED. Dari analisa struktur sekunder melalui situs http://www.bioinf.cs.ac.uk/ menu PSIPRED didapatkan bahwa protein CAT normal dan mutan memiliki struktur sekunder yang tersusun dari heliks dan koil.

Struktur 3D protein CAT terdiri atas bentuk heliks (warna merah) dan koil (warna hijau). Struktur 3D Ala110Val CAT sama dengan struktur 3D CAT normal, hanya berbeda pada asam amino no 110 yang mengubah Alanin menjadi Valin.

Mutasi misssense SNP Ala110Val (C330T, rs1001179) terletak di struktur 3D CAT pada asam amino urutan ke 110 yang mengubah Alanin (A) menjadi Valin(V) (data RefSNP/dbSNP rs1001179).

Selanjutnya untuk menganalisa fungsi protein mutan terlebih dulu dicari situs aktif dari protein CAT pada www.expasy.com menu Prosite. Protein CAT mempunyai 5 situs aktif yaitu: situs $\mathrm{N}$ miristoilasi pada posisi basa $32-37,121$ 126, 204-209, 399-404, 516-521; situs Amidasi pada posisi basa 103-106; situs fosforilasi protein kinase C (PKC) pada posisi basa 125-127, 167-169, 187-189, 201-203， 219-221， 271-273， 301-303; situs fosforilasi casein kinase II (CK II) pada posisi 125-128, 246-249, 254-257, 417-420, 434-437; $\mathrm{N}$ glikosilasi pada posisi basa 244-247, 439-442 dan fosforilasi Tyrosin kinase pada posisi 252260. Dari data situs aktif tersebut, dilakukan rekontruksi protein mutan Ala110Val dengan PYMOL.

Dari hasil rekontruksi ini ternyata posisi SNP pada basa 110 merubah Alanin menjadi Valin, dengan mengubah kodon 
GCC menjadi GTC. Situs ini berdekatan letaknya dengan situs amidasi.

Posisi yang berdekatan ini diperkirakan akan mengganggu fungsi amidasi dari protein CAT sehingga berpengaruh pada ekspresi CAT. Terganggunya ekspresi CAT menyebabkan peningkatan terhadap berkurangnya ekspresi CAT, sehingga menyebabkan defisiensi CAT yang berakibat turunnya aktivitas enzim antiksidan CAT.

Hal ini menyebabkan toksisitas $\mathrm{H}_{2} \mathrm{O}_{2}$ pada sel beta pankreas meningkat, sehingga menurunkan sekresi insulin yang menjadi faktor resiko pada disbetes tipe 1 . Hal ini dapat dijadikan dasar dalam biologi molekuler dalam mempelajari patomekanisme dari diabetes tipe 1 .

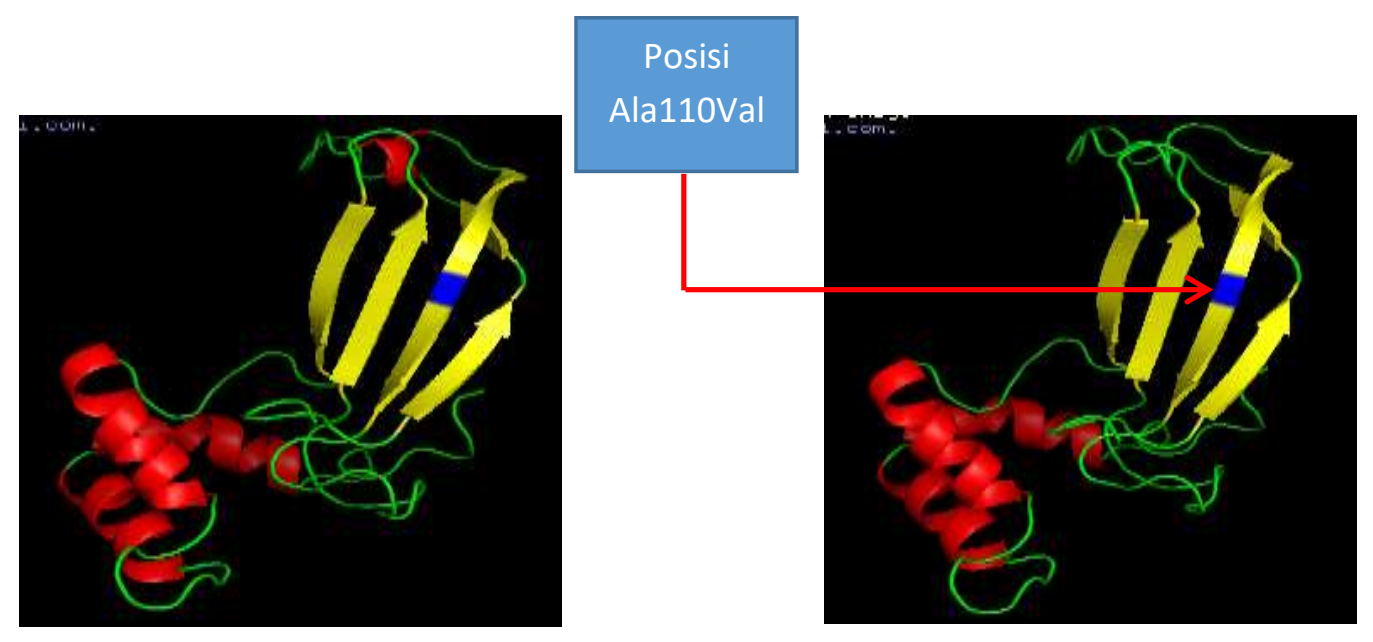

Gambar 1. Struktur 3D dari CAT normal (A) dan mutan (B)

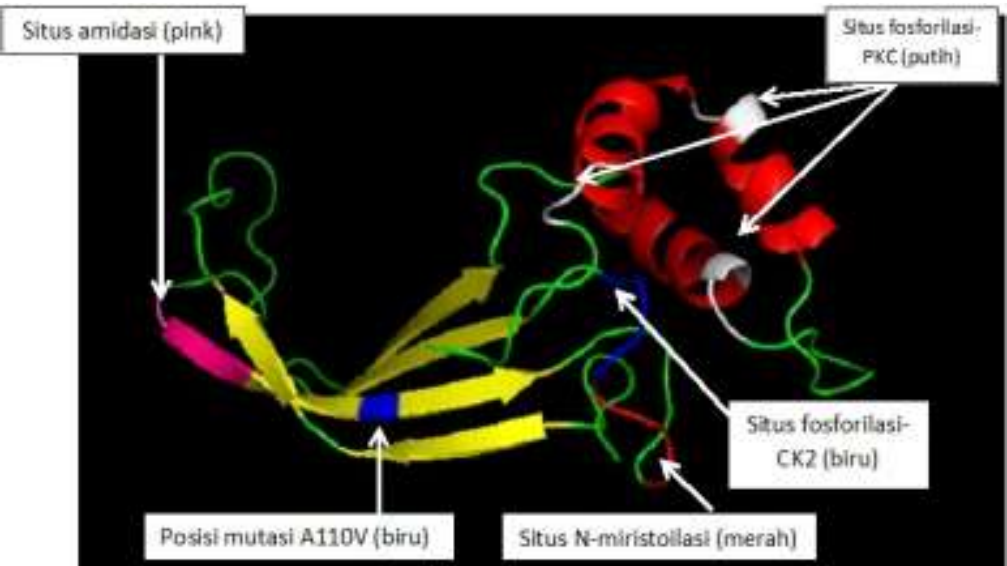

Gambar 2. Struktur 3D dari CAT normal (A) dan mutan (B) dengan situs aktivasi Ala110Val. 
Disain Primer dan Situs Rektriksi CAT

Primer yang didapat dari www.ncbi.nlm.gov menu BLAST dilakukan analisis menggunakan program NetPrimer, dan dipilih primer yang terbaik sesuai dengan karakteristik primer yang baik.Dari analisis ini didapatkan disain primer yang dipilih untuk mutasi CAT C330T adalah :

Forward primer:

CAGATGCAGCACTGGAAGGA

dengan panjang $20 \mathrm{bp}, \mathrm{Tm}=59,18^{\circ} \mathrm{C}$

Reverse primer:

CCCGATTCTCCAGCAACAGT

dengan panjang $20 \mathrm{bp}, \mathrm{TM}=59,81^{\circ} \mathrm{C}$

Analisis selanjutnya dilakukan terhadap kedua primer diatas, dengan menggunakan Perl Primer untuk melihat stabilitas primer tersebut. Kemudian dilakukan alimenasi primer untuk menunjukkan spesifitas primer tersebut. Dari analisis ini didapatkan bahwa $\Delta \mathrm{G}$ forward primer $-22,22 \mathrm{kcal} / \mathrm{mol}$ dan reverse primer $\Delta \mathrm{G} \quad-22,24 \mathrm{kcal} / \mathrm{mol}(<-3$ $\mathrm{kkal} / \mathrm{mol})$, yang berarti kedua primer ini stabil.

Selanjutnya dilakukan pencarian enzim restriksi untuk mengenali mutasi CAT C330T. Hal ini dilakukan dengan menggunakan software BREBASE dengan pilihan NEBcutter. Mutasi C330T CAT dapat dideteksi dengan menggunakan metode restriction fragment length polymorphism (RFLP) menggunakan enzim restriksi. Dari analisis ini, didapatkan enzim rektriksi yang dapat memotong situs $\mathrm{G}$ dan $\mathrm{C}$ pada posisi 330 adalah CviKI-1. Enzim rektriksi CviKI-1 dapat memotong situs antara basa $\mathrm{G}$ dan $\mathrm{C}$ dengan pola blunt end. Pada individu normal/wildtype maka situs GC akan dapat dikenali, tapi pada individu mutan dimana terjadi perubahan $\mathrm{C}$ menjadi T, maka situs mutan (GT) tidak dapat dikenali oleh enzim CviKI-1. Dari data analisis menggunakan situs REBASE menu NEBCutter didapat juga enzim rekstriksi yang lain yaitu enzim rektriksi Hae III yang memotong $\mathrm{G}$ dan $\mathrm{C}$.

\section{PENUTUP}

Kajian Bioinformatika pada gen CAT dan tipe mutannya C330T ini memberikan berbagai informasi yang bermanfaat dalam menjebatani pengetahuan dasar tentang CAT dengan patomeknisme dari penyakit yang terjadi akibat mutasi pada gen CAT. Dari analisa ini ternyata mutasi pada C330T berkaitan dengan diabetes tipe 1 . Hal ini disebabkan akibat terjadinya mutasi pada gen CAT, sehingga menyebabkan menurunnya ekspresi gen CAT. Hal ini mengakibatkan berkurangnya aktivitas CAT sebagai biokatalisator dan enzim antioksidan dalam merubah $\mathrm{H}_{2} \mathrm{O}_{2}$ yang bersifat toksik terhadap sel -(termasuk sel beta pankreas sebagai penghasil insulin) menjadi $\mathrm{H}_{2} \mathrm{O}$ dan $\mathrm{O}_{2}$.

\section{DAFTAR PUSTAKA}

Chistiav D.A, Savostanov K.V, Torakulov R.I, et al. (2004). Anew type 1 diabetes susceptibility locus containing the catalase gene (chromosome 11p113) in a Russian population. Diabetces Metab .Res. Rev; 20 (3): 219-22.

Chistikov D.A, Zotova E.V, Sovost'áno K.V, et al. (2006). The C262T promoter polymorphism of the catalase gene is associated with diabetic neuropathy in type 1 diabetic Russian patients.Diabetes metab; 32(1): 63-68

Fosberg L., Lyrrenas et al., (2001). A common functional C-T substitution polymorphisme in the promoter region of human catalase gene influences transcription factor binding, reporter gene trasncription and is correlated to blood catalase levels. Free Radic, Biol, Med, 2001; 30: 500-505. 
Franco A, Dolzan V.M, Areric N. (2008). Asbestosis and catalase genetic polymorphism.Arh.Hig.Rada.Toxico, 2008; 59: 233-240.

Goth L, Shemirani A, Kalmir. (2000). A novel catalase mutation (a GA insertion) causes the Hungarian type of acatalasemia. Blood Cells. Mol \& Dis; 26(2): 151-154.

Goth L, Rass P, Madarasi I. (2005). Detection of novel familial catalase mutation (Hungarian type D) and the posible risk of inherited catalase deviciency for dibabetes melitus. Electropjoresis; 26: 1646-1649

Goth L, Eaton J.W. (2000). Hereditary catalase deficiencies and increased risk of diabetes. Lancet; 356: 1820-1821.

Hamilton, Howard B, Neel J.V. (1963). Genetic heterogeneity in human Acatalesemia. Am. J. Hum. Genet; 15(4): 408-419.

Kodydkova J, Vavrova L, Kocik M, Zak A. (2014). Human catalase, its polymorphisms, regulation and changes of its cctivity in different diseases., Folia Biologica; 60(4): 153-167

Kishimoto Y, Murakami Y, Hayashi K, Takahara S, Sugimura T, Sekiya T. (1992). Detection of a common mutation of the catalase gene in Japanese acatalasemic patients. Hum. Genet; 88: 487-490

Ogata M, Wang D.H, Ogino K. (2008). Mamalian acatalasemia: the perspective of bioinformatics and genetic toxicology,Acta Med Okayma; 62: 345361

Tarnai I, Csordas M, Sukei E, Shermiran Goth L. (2007). Effect of C111T polymorphism in exon 9 of the catalase gene on blood catalase activity in different type of diabetes mellitus. Free Radic, Res; 4: 806-811.

Wen J.K, Osumi T, Hashimoto T, Ogata M. (1990). Molecular analysis of human acatalasemia: identification of a splicing mutation. J. Mol. Biol. 211(2): 383-393. 